orange, probably indicating, according to Prof. W. H. Pickering, a different chemical constitution.

The radiant appeared to cover a considerable area, about $8^{\circ}$ in diameter, and seemed to be double, the two principal centres being situated at R.A. $=9 \mathrm{~h} .56 \mathrm{~m}$. , dec. $=+24^{\circ}$, and at R.A. $=9$ h. 4 om., dec. $=+26^{\circ}$

Although elaborate preparations were made for securing photographs, only two trails appeared on the resulting negatives. One, due to a Leonid, commenced at R.A.= 9 h. $17 \cdot 2 \mathrm{~m}$., dec. $=+28^{\circ} 57^{\prime}$, and ended at R.A. $=9 \mathrm{~h} .8 .8 \mathrm{~m}$. dec. $=+29^{\circ} 5^{\prime}$, a more careful measure showing that the meteor passed through a point having the position R.A. $=9$ h. $57 \cdot 0$ m., dec. $=+24^{\circ} 14^{\prime}(1855)$. The other trail extended from R.A. $=4 \mathrm{~h} .52 \cdot 5 \mathrm{~m}$., dec. $=+0^{\circ} 5^{2}$, to R.A. $=5$ h. $10.7 \mathrm{~m}$. , dec. $=-4^{\circ} 39^{\prime}(1855)$, and was, therefore, not due to a Leonid (Harvard College Observatory Circular, No. 89).

Light-curve of $\delta$ Cephei.-Employing the method used by Dr. W. J. S. Lockyer in his discussion of the observations of $\eta$ Aquilæ (Göttingen, 1897), Dr. B. Meyerman has reduced the observations of $\delta$ Cephei.

As a result he obtained the following as the formula for determining the epochs of maxima :-

$$
1840 \text { September } 26 \cdot 35^{88}+5 \cdot 366404 \text { E. (Bonn). }
$$

A comparison of the phases determined from this formula with observed values gives small differences which compare favourably with those previously obtained by other observers. The new observations are consistent with an invariable period (Astronomische Nachrichten, No. 3985).

Structure of the Third Cyanogen Band.-Some interesting results concerning the structure of the third rwanogen band have been obtained by Herr Franz Jungbluth at Bonn. By employing the third order of a Rowland grating having 630 lines to the millimetre (i.e. about 16,000 to the inch) and a focal length of 6.6 metres (about $2 \mathrm{r} \cdot 6$ feet), he obtained a greater dispersion than has hitherto been used for this purpose.

His results, stated briefly, are as follow:--(I) the third cyanogen band consists of double lines; (2) the maximum intervals between successive lines in the four strongest series form an arithmetical progression; (3) the view of King, that the inverted " heads" are to be regarded as " tails" of the bands connected with the known "heads," possesses a high degree of probability; (4) the connection of groups of "heads" and "tails" is such that the first "head" and the last "tail" belong to the same series, the second "head" to the penultimate "tail," and so on ; (5) the hypothesis of Thiele, that the intervals between successive lines in a band increase only to a certain point and then decrease until the series ends in a tail, appears to be correct; (6) the lengths of the successive series form an arithmetical progression (Astrophysical Journal, vol. xx., No. 4).

New Refraction Tables.-A set of new refraction tables whereby one may find the refraction correction to 0.01 of a second of arc are given in No. 3983 of the Astronomische Nachrichten by Dr. L. de Ball, of Vienna. The tables are adaptable to a range of atmospheric temperatures and pressures and of zenith distances. Knowing the temperature and pressure at the place of observation, one finds the logarithm of the actual density of the atmosphere from table i., and with this and the known zenith distance finds the refraction correction to the second decimal of a second of arc from table ii.

The "ANnuare" du Bureau des Longttudes.-Continuing the scheme inaugurated in last year's "Annuaire", for the alternation of various subjects in the successive issues, the volume for this year contains, in addition to the astronomical data, tables regarding statistics, geography, \&c., to the exclusion of data for chemistry and physics.

The astronomical section contains, among many other things, the following useful information:-A table for calculating the altitude from readings of the barometer, a complete table of the elements of variable stars of known periods, tables of stellar parallaxes, double stars and proper motions, and an article of stellar spectroscopy by $\mathrm{M}$. Gramont, whilst the sun-dial, solar physics, the table of minor planets, \&c., are reserved for the issue of 1906. No. I 836 , VOL, 7 I]
Eclipse Results and Problems.-In the December (igo4) number of the Bulletin de la Société astronomique de France M. le Comte de la Baume Pluvinel reviews the results obtained during the total solar eclipses of the last thirty years, and in connection with the study of each eclipse phenomenon he outlines the problems which yet require further elucidation. To those interested in eclipse work the article will be found to be a useful resume.

Bibliography of Contemporary Astronomical Works. - We have received from Prof. Ernest Lebon, of the Lycée Charlemagne, Paris, an extract from a plan of an analytical bibliography of contemporaneous writings on historical work in astronomy, as submitted by him to the International Congress of Historical Science held at Rome in April, 1903. Judging from the list of authors named in the plan and the specimen extracts given therein, the bibliography will be found extremely useful by those workers in astronomy who have occasion to refer to previous results obtained since 1846 .

\section{PRIZES PROPOSED BY THE PARIS ACADEMY OF SCIENCES FOR 1905.}

CEOMETRY.-The Francour prize (1000 francs), for discoveries or work useful for the progress of pure or applied mathematics; the Poncelet prize (2000 francs), for work in applied mathematics.

Mechanics.-A Montyon prize (700 francs), for the invention or improvement of instruments useful in the progress of agriculture, the mechanical arts or sciences; the Poncelet prize (2000 francs), for a work on applied mathematics; the Fourneyron prize (I000 francs), for a memoir on the theoretical or experimental study of steam turbines.

Navigation. - The extraordinary prize of 6000 francs as a recompense for any work tending to increase the efficiency of the French naval forces; the Plumey prize (2500 francs), for an improvement in steam engines or any other invention contributing to the progress of steam navigation.

Astronomy.-The Pierre Guzman prize (100,000 francs), for the discovery of a means of communicating with any celestial body other than the planet Mars; failing the award of the capital sum, the interest will be awarded every five years for a work important to the progress of astronomy. The Lalande prize (540 francs), for the observation, memoir, or work most useful to the progress of astronomy; the Valz prize ( 460 francs), and the G. de Pontécoulant prize (700 francs), under similar conditions. The Damoiseau prize (2000 francs); the question proposed for this prize is as follows:- - there are a dozen comets the orbit of which, during the period of visibility, is shown to be of a hyperbolic nature. The problem set is to find out whether this was the case before the arrival of the comet in the solar system, going back to the past history of the comet, and allowing for the perturbations of the planets.

Geography.-The Gay prize (1500 francs), for an explorer in Africa who has determined with great precision the geographical coordinates of the principal points on his journey; the Tchihatchef prize (3000 francs), as a recompense or encouragement for naturalists of any nationality who have most distinguished themselves in the exploration of the Asiatic continent, more especially in the lesser known regions; the Binoux prize (2000 francs).

Physics.-The Hébert prize (rooo francs), for a discovery or treatise on the popular applications of electricity; the Hughes prize (2500 francs), for a work contributing to the progress of physics; the Gaston Plante prize (3000 francs), for a discovery, invention, or important work in the field of electricity; the L. la Caze prize (10,000 francs), awarded in one sum for works important in physics.

Chemistry.-The Jecker prize (ro,ooo francs), for work in organic chemistry; the Cahours prize ( 3000 francs), for the encouragement of young chemists; the Montyon prize, unhealthy trades ( 2500 francs and a mention of $1_{500}$ francs), for a means of rendering a trade less unhealthy or dangerous; the L. la Caze prize (10,000 francs), for the best work on chemistry during the last two years; the Bordin prize (3000 francs), for a memoir on the silicides and the part played by them in metallic alloys.

Mineralogy and Geology.-.The Delesse prize (I 400 
francs), for a work concerning geology, or, failing that, mineralogy; the Iontannes prize (2000 francs), for the best publication on palæontology; the Alhumbert prize (1000 francs), for a memoir on the period of the last volcanic eruptions in France.

Botany.-The grand prize of the physical sciences (3000 francs); the question proposed is the demonstration of the various modes of formation and development of the egg in the Ascomycetes and the Basidiomycetes. The Desmazieres prize (Iboo francs), for the best work published during the preceding year on Cryptogams; the Montagne prize ( 1500 francs), for work having for its object the anatomy, physiology, development, or the description of the lower Cryptogams; the "Thore prize (200 francs) for work on the cellular Cryptogams of Europe.

Anatomy and Zoology.-The Savigny prize ( 300 francs), for the assistance of young travelling zoologists, not receiving Government assistance, who have especially occupied themselves with the invertebrates of Egypt and Syria.

Medicine and Surgery.-A Montyon prize (2500 francs and a mention of 1500 francs), for works and discoveries useful in the art of healing; the Barbier prize (2000 francs), for a valuable discovery in surgical, medical, or pharmaceutical science, or in botany having relation with medicine; the Bréant prize (100,000 francs), for the discovery of an absolute specific against Asiatic cholera, or to point out in an irrefutable manner the causes of Asiatic cholera, so that the suppression of the disease will follow. Failing the award of the capital sum, the annual interest will be given for a rigorous demonstration of the existence in the atmosphere of matter capable of playing a part in the production or propagation of epidemic diseases. The Godard prize (1000 francs), for the best memoir on the anatomy, physiology, and pathology of the genito-urinary organs; the Baron Larrey prize ( $75^{\circ}$ francs), for the best work dealing with the subject of military medicine, surgery, or hygiene; the Bellion prize ( 1400 francs); the Mège prize (Io,00o francs); the Serres prize (7500 francs), for a memoir on general embryology applied as far as possible to physiology and medicine; the Dusgate prize (2500 francs), for the best work on the diagnosis of death and the prevention of premature burial.

Physiology.-A Montyon prize (750 francs), and the Philipeaux prize (900 francs), for work in experimental physiology; the Lallemand prize ( 1800 francs), for work on the nervous system; the Pourat prize (rooo francs), for an essay on the origin of muscular glycogen.

Statistics.-A Montyon prize (500 francs), for a memoir on French statistics.

Among the general prizes offered in 1905 are the following :- the Binoux prize (2000 francs), for a work on the history of science; the Trémont prize (r roo francs), the (iegner prize ( 3800 francs), the Lannelongue prize (I200 francs), the Wilde prize (400o francs), the Saintour prize (3000 francs), the Petit d'Ormoy prizes (two of 10,000 francs), all for work useful in the promotion of scientific knowledge. Of these prizes those bearing the names of Pierre Guzman, Lalande, Tchihatchef, La Caze, Delesse and Desmazières are especially mentioned as being awarded without distinction of nationality.

\section{GEOLOGICAL NOTES.}

VERY little geological information appears to have been published on the State of Durango, in western Mexico. The observations therefore recorded during a brief journey by Dr. O. C. Farrington are of considerable interest (Field Columbian Museum, No. 89, geological series, vol. ii., No. 5). His route extended from the city of Durango, which is situated upon an alluvial plain hemmed in by low and rugged hills, to the silver-mining town of Villa Corona or Ventanas, distant about seventy miles in a direct line. The ground, which forms part of the interior plateau of Mexico, rises from about 6000 feet at Durango to 9000 feet. While large tracts of the area are semi-arid and sparsely covered with soil and vegetation, in some places corn is successfully grown, and elsewhere there occur extensive pine forests with caks. Views of the scenery are given. Eruptive rocks prevail, and near the Ciudad ranch, on one of the highest parts of the plateau, there is a tract of weathered masses known as La Ciudad de Rocas ("The City of Rocks"). The outlines of the rocks are domed and rounded, and they appear to be due to the weathering of fairly homogeneous rhyolitic materials.

Particular attention is directed by the author to the famous Cerro Mercado or Iron Mountain, a hill largely made up of solid iron-ore, and situated less than a mile north-east of Durango City. It rises abruptly from the alluvial plain to an average height of about 300 feet, with single peaks 50 feet to 100 feet higher. The length of the hill is about $1 \frac{1}{3}$ miles, and its average width about onethird of a mile. The ore appears to be chiefly hæmatite, although some magnetite also occurs; in physical characters it varies, being hard and soft, black, red, specular, and earthy. Hard, solid black ore, however, forms the chief mass of the "mountain," the black colour being in striking contrast to the yellow and green of the surrounding plain. The ridge is almost bare of vegetation, except for straggling cacti, and its outline is bold and rugged. Steep cliffs Io feet to 20 feet high are not infrequent, and in places they exhibit a distinct columnar structure like that of basalt (see Fig. I). The existence of this hill appears to have been made known in $155^{2}$ A.D. but the first serious attempt to work the iron-

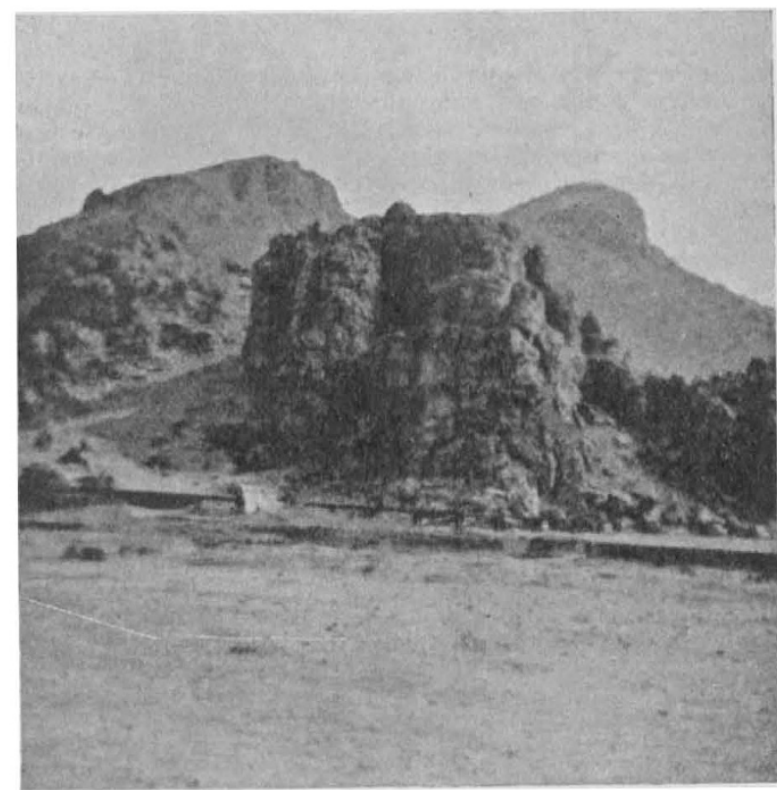

FIG. 1.-Cliff showing columnar siructure of iron-ore at western end of the Cerro Mercado or Iron Mountain of Durango, Mexico.

ore was made in 1828 . Successful operations were not conducted until r888, and only within the last five years has a steady production been maintained. The amount of ore exposed above the level of the plain is estimated at 360 million tons. The author briefly discusses the origin of the iron-ore, regarding it as probably igneous. The associated rocks of the district are rhyolites, probably of later Tertiary age, but the relation, either in time or manner of origin, between the associated eruptive rock and the iron-oxide, and the origin of the iron-oxide itself, seem as yet difficult to determine.

A geological description of the Baraboo iron-bearing district of Wisconsin, by Dr. Samuel Weidman, has been issued by the Wisconsin Geological and Natural History Survey (Bulletin No. 13, economic series No. 8). The area is formed mainly by pre-Cambrian quartzites, which stand out in bold north and south ranges, so connected both on the east and west as to constitute a cordon of bluffs enclosing a depressed drift-covered interior. Isolated areas of still older rocks, rhyolite, granite, and diorite, occur along the outer borders of the ranges. Potsdam sandstone is found beneath the drift, and on the slopes of the Baraboo quartzites, while later Palæozoic strata are met with at higher levels. Special interest has recently been aroused by 